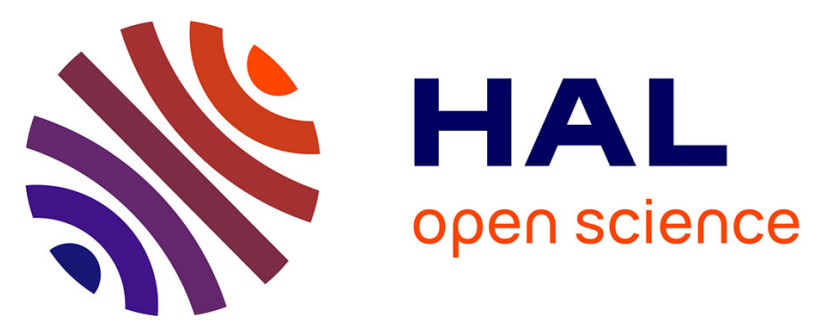

\title{
Implications of Sediment Dynamics in Mass Transport along the Pianosa Ridge (Northern Tyrrhenian Sea)
}

Elda Miramontes, Antonio Cattaneo, Gwenael Jouet, Sebastien Garziglia

\section{To cite this version:}

Elda Miramontes, Antonio Cattaneo, Gwenael Jouet, Sebastien Garziglia. Implications of Sediment Dynamics in Mass Transport along the Pianosa Ridge (Northern Tyrrhenian Sea). Geoffroy Lamarche, Joshu Mountjoy, Suzanne Bull, Tom Hubble, Sebastian Krastel, Emily Lane, Aaron Micallef, Lorena Moscardelli, Christof Mueller, Ingo Pecher, Susanne Woelz. Submarine Mass Movements and their Consequences. , 41, Springer, pp.301-309, 2016, Advances in Natural and Technological Hazards Research, 978-3-319-20978-4. 10.1007/978-3-319-20979-1_30 . hal-01687792

\section{HAL Id: hal-01687792 https://hal.science/hal-01687792}

Submitted on 23 Jan 2018

HAL is a multi-disciplinary open access archive for the deposit and dissemination of scientific research documents, whether they are published or not. The documents may come from teaching and research institutions in France or abroad, or from public or private research centers.
L'archive ouverte pluridisciplinaire HAL, est destinée au dépôt et à la diffusion de documents scientifiques de niveau recherche, publiés ou non, émanant des établissements d'enseignement et de recherche français ou étrangers, des laboratoires publics ou privés. 


\title{
Implications of Sediment Dynamics in Mass Transport along the Pianosa Ridge (Northern Tyrrhenian Sea)
}

\author{
Elda Miramontes, Antonio Cattaneo, Gwenael Jouet, and Sebastien Garziglia
}

IFREMER, Géosciences Marines-EDROME, Centre de Brest, BP70, CS10070, 29280

Plouzané, France. elda.miramontes.garcia@ifremer.fr

\begin{abstract}
The Pianosa Ridge forms the eastern flank of the Corsica Trough in the Northern Tyrrhenian Sea: it is the site of preferential accumulation of contourites and Mass Transport Deposits (MTDs). Along the Pianosa Ridge, eleven MTDs with a total volume of $6.5 \mathrm{~km}^{3}$ were identified. These MTDs are distributed in three areas: A) one small MTD associated to canyon flank destabilisation in the northern part of the study area; B) six intermediate size MTDs in the central area; C) four MTDs of larger size (up to $2.62 \mathrm{~km}^{3}$ ) to the south, including the Pianosa Slump, which is the most recent MTD in this area (aged at 42 to $50 \mathrm{kyr}$ BP) and analysed in more detail. The main factor controlling the formation of MTDs in areas A and B seems to be steep slopes associated to erosion and heterogeneous sedimentation caused by bottom currents, respectively. In contrast, multiple factors may control slope instability in the zone where the largest MTDs took place (area $\mathrm{C}$ ): the incision generated by contour currents, the presence of coarser layers in contourite drifts that may accumulate gas and the location of normal faults near the headwall.
\end{abstract}

Keywords Mass transport deposit, Contourite, Pockmark, Tyrrhenian Sea

\section{Introduction}

The Corsica Trough is located between Corsica and the Tuscan Shelf in the Northern Tyrrhenian Sea. It has a maximum depth of $900 \mathrm{~m}$ and connects the Tyrrhenian and Ligurian Seas. The eastern flank of the Corsica Trough is formed by the Pianosa Ridge, a tectonic structure with typical slopes between $3^{\circ}$ and $10^{\circ}$, reaching $20^{\circ}$ locally (Fig. 1). This area is characterised by several submarine landslides and contourite deposits (Cattaneo et al. 2014; Fig. 1). Contourite drifts are formed by the Levantine Intermediate Water (LIW), flowing northwards (Artale and Gasparini 1990) and generating stronger bottom currents on the Pianosa Ridge due to the Coriolis force. The sediment input from the Tuscan Shelf is low since sediment from Italian rivers is mostly trapped in the shelf and cannot reach the 


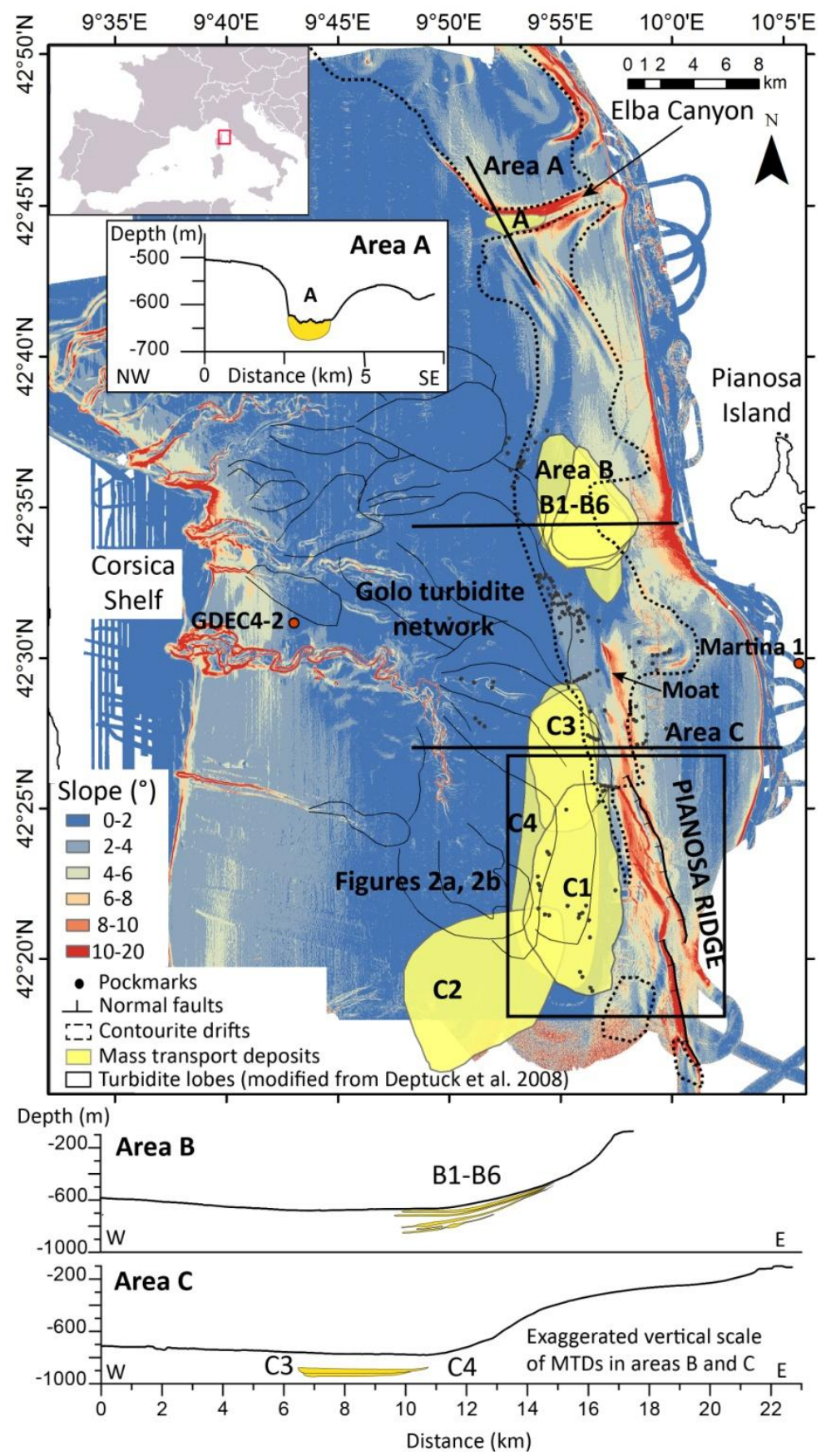

Fig. 1 Seafloor gradient map of the Corsica Trough with superposed location of morphosedimentary features: Mass Transport Deposits (MTDs), contourite drifts and turbidite lobes (see legend). Three bathymetric cross-sections across areas A, B and C show the location of MTDs 
Corsica Trough (Roveri 2002). Most of the sediment deposited in the Corsica Trough is transported from the Corsica shelf by the Golo turbidite network (Deptuck et al. 2008; Fig. 1).

The aims of this study are to present the size and the stratigraphic distribution of Mass Transport Deposits (MTDs) along the Pianosa Ridge, and to analyse their relationship with the pre-existing seabed morphology.

\section{Material and Methods}

In 2013 two cruises, PRISME2 and PRISME3 onboard the R/V Atalante and R/V Pourquoi pas?, respectively, took place along the Pianosa Ridge. Multibeam bathymetry, 72-channel high-resolution mini GI gun $(50-250 \mathrm{~Hz})$ and CHIRP $(1800-5300 \mathrm{~Hz})$ seismic reflection profiles, and Calypso piston cores were collected along the Pianosa Ridge. P-wave velocity was measured on whole core sections using a Geotek Multi-Sensor Core Logger (MSCL). The bulk sediment semiquantitative geochemical composition was measured with an Avaatech X-ray fluorescence (XRF) core scanner on split cores. Radiocarbon dating was obtained from bulk planktonic foraminifera at the Poznan radiocarbon laboratory. Radiocarbon ages were corrected for a marine reservoir effect of 400 years and calibrated using Calib 7.0.2 radiocarbon calibration software and the IntCal13 calibration curve (Reimer et al. 2013). MTDs were identified by seismic facies validated by the analysis of equivalent coring samples. MTD volume was calculated using the Kingdom Suite ${ }^{\circledR}$ software by quantifying the time interval between the top and the bottom of the MTD from the seismic profiles. The velocity applied for time-depth conversion $(1550-1560 \mathrm{~m} / \mathrm{s})$ was obtained from the velocity analysis calculated with the ProMAX ${ }^{\circledR}$ Seismic Processing Software.

\section{Results}

Along the Pianosa Ridge 11 MTDs were identified in the Quaternary sediment record. Differences in location, volume and morphology were used to distinguish three areas of MTDs: A, B and C (Table 1). Seismic correlation with the borehole GDEC4-2 (Fig.1; Angue Minto'o 2014) provided information about the stratigraphy in the region.

Area A shows a small submarine landslide associated to the destabilisation of the northern flank of the Elba Canyon (west of the Elba Island), where the slope is $8^{\circ}$ to $20^{\circ}$. The headwall scarp and the deformation features of the MTD are clear in the bathymetry (Fig. 1). MTD A is of Holocene age, since it affects a regional reflector dated at $12 \mathrm{kyr}$.

Six small to intermediate size MTDs (B1 to B6) are observed in area B (Table 1). They are located west of the Pianosa Island, where the Pianosa Ridge forms an edge, generating in this zone high slope gradients $\left(8-10^{\circ}\right)$. The MTDs have an oval shape in plan view. B1, B2, B3 and B4 have a mean thickness of about 10 m; B5 and B6 mean thickness is $5 \mathrm{~m}$. The continental slope in area B is starved during 
Pliocene and Quaternary. Pre-Messinian deposits (age deduced by correlation with the well Martina 1; Figure 1; Pascucci et al. 1999) crop out in patches on the upper slope. Despite the reduced size of these MTDs, their thickness corresponds to about $30 \%$ of the Pliocene-Quaternary deposits in the lower continental slope. B6 and B5 MTDs are older than $542 \mathrm{kyr}$, while the sediment covering B4 was deposited at $452 \mathrm{kyr}$, based on correlation to the bottom of borehole GDEC4-2. B3 is close in time to B4 but separated by $300 \mathrm{kyr}$ from B2 (Table 1). B1 is the most recent MTD (42-59 kyr) in area B, it took place about $80 \mathrm{kyr}$ after B2. The frequency of MTDs in area B is irregular and it was higher during the Middle Pleistocene than during the Upper Pleistocene.

Four MTDs ( $\mathrm{C} 1$ to $\mathrm{C} 4)$ are located in area $\mathrm{C}$, in the southern zone of the study area. Their volume ranges from 0.67 to $2.62 \mathrm{~km}^{3}$ and they are characterised by a high width/length ratio, except for $\mathrm{C} 2$ that has a ratio lower than 1 (Table 1). Between 265 and $380 \mathrm{kyr}$ BP C3 and C4 were formed, followed by C2 at 125-160 kyr (Table 1). The Pianosa Slump (C1) is the most recent MTD of area $\mathrm{C}$ and it was analysed in more detail than the other MTDs since it was sampled by the Calypso piston core PSM3-CS022 (Figs. 2, 3). The top of C1 (i.e. the bottom of the post-slide hemipelagic sediment; Fig. 3) is dated at 42,326 cal yr BP and Cattaneo et al. (2014) report that the MTD disrupted sediments as old as 50,000 cal yr BP. $\mathrm{C} 1$ is overlain by about 17 to $20 \mathrm{~m}$ of sediment (Fig. 3). However, various morphological features related to MTD C1 can still be appreciated at the present seafloor (Fig. 2).

Table 1 Characterisation of Mass Transport Deposits in areas A, B and C

\begin{tabular}{cccccccc}
\hline Area & Name & $\begin{array}{c}\text { Volume } \\
\left(\mathrm{km}^{3}\right)\end{array}$ & $\begin{array}{c}\text { Maximum } \\
\text { runout }(\mathrm{km})\end{array}$ & $\begin{array}{c}\text { Maximum } \\
\text { length }(\mathrm{km})\end{array}$ & $\begin{array}{c}\text { Width } \\
(\mathrm{km})\end{array}$ & $\begin{array}{c}\text { Width/Length } \\
\text { ratio }\end{array}$ & Age (kyr BP) \\
\hline A & A & 0.10 & 1.5 & 1.2 & 3.6 & 3.0 & $<12$ \\
B & B1 & 0.19 & 7.0 & 5.7 & 7.6 & 1.3 & $42-59$ \\
& B2 & 0.09 & 8.0 & 5.6 & 4.6 & 0.8 & $125-137$ \\
& B3 & 0.26 & 7.5 & 5.9 & 7.2 & 1.2 & $420-437$ \\
& B4 & 0.15 & 4.2 & 2.5 & 7.4 & 3.0 & $452->542$ \\
& B5 & 0.05 & 6.0 & 3.4 & 4.4 & 1.3 & $>542$ \\
& B6 & 0.04 & 6.2 & 3.6 & 4.4 & 1.2 & $>542$ \\
C & C1 & 2.62 & 9.0 & 6.0 & 13.5 & 2.3 & $42-50$ \\
& C2 & 0.47 & 16.0 & 10.0 & 7.8 & 0.8 & $125-160$ \\
& C3 & 0.67 & 6.0 & 4.0 & 8.7 & 2.2 & $265-321$ \\
& C4 & 1.86 & 10.4 & 5.3 & 18.6 & 3.5 & $321-380$ \\
\hline
\end{tabular}

The headwall domain of $\mathrm{C} 1$ has the same lateral extent as the Pianosa Slump deposit. However, the headwall morphology is rather irregular. In the northern part, the headwall is continuous, parallel to a normal fault (Fig. 2b). It is connected to the MTD by a sidewall that is $30 \mathrm{~m}$ high at the present seafloor. South of this zone, the slope is cut by multiple discontinuous headwalls and scarps. $\mathrm{C} 1$ is composed of three main parts (Figs. 2b, 2c) deduced from seismic profiles, bathymetry and Calypso piston core PSM3-CS022 (Fig. 3): 1) strongly deformed sediment, 2) fold and thrust system and 3 ) tilted blocks. The strongly deformed sediment corre- 
sponds to chaotic seismic facies that are present in the central northern part and in the southern part of $\mathrm{C} 1$, where the headwall is discontinuous. In this area the surface morphology shows lobate shapes and crests that indicate a movement towards the west that turned slightly to the southwest, in the direction of increasing depth. The MTD thickness of the southern part shows that there is a deposit at the foot of the slope up to $50 \mathrm{~m}$ thick and a thicker zone $(50-70 \mathrm{~m})$ in the central distal part.

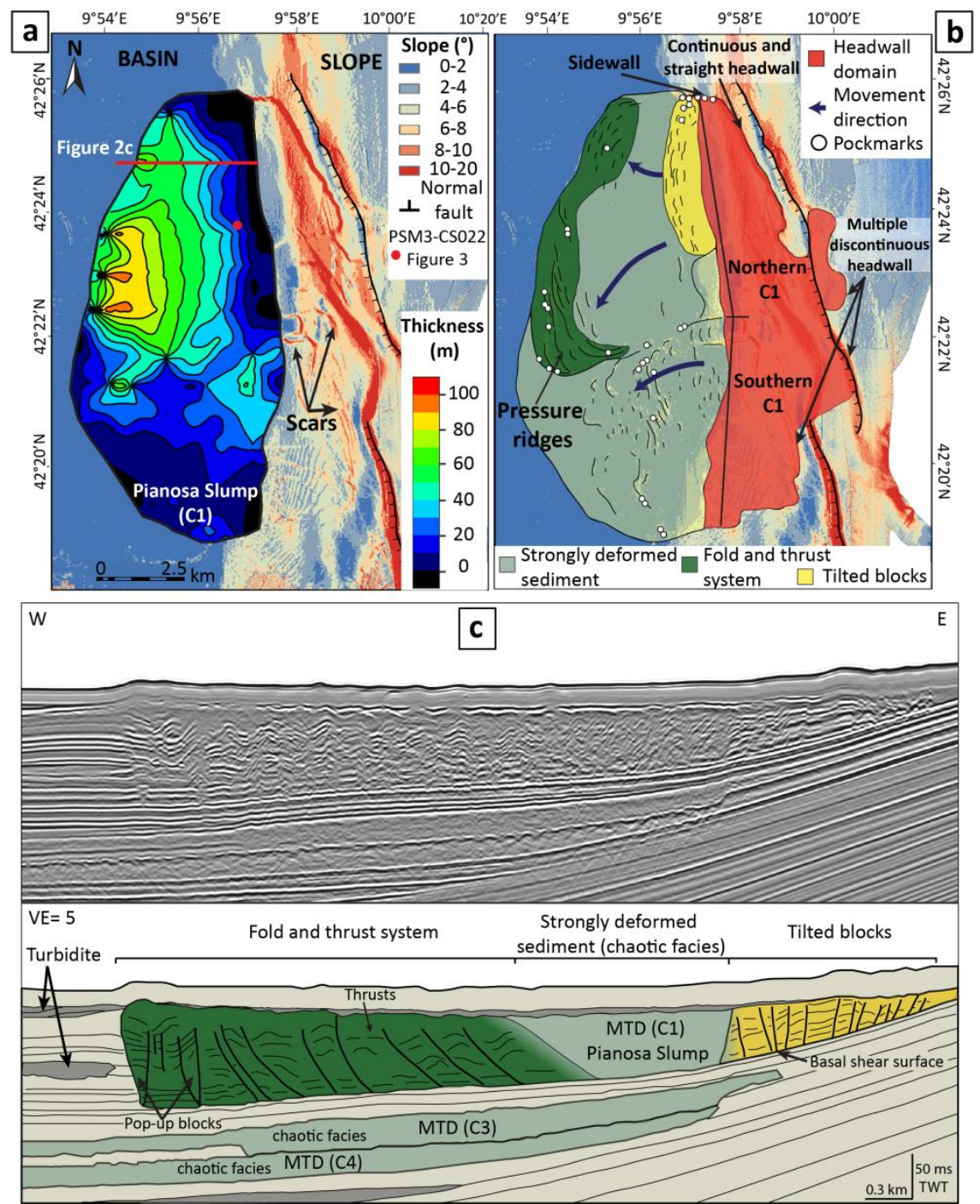

Fig. 2 a Isopach map of the Pianosa Slump (C1) overlaying the present seafloor gradient map with the location of Calypso piston core PSM3-CS022 b Morphological interpretation of C1 $\mathbf{c}$ Multichannel high-resolution mini GI gun seismic reflection profile across MTDs C1, C3 and C4 and line drawing with the interpretation 
In the northern part of $\mathrm{C} 1$ the internal structure of the deposit is more complex than in the southern part. In this area the toe domain of the MTD is formed by a fold and thrust system. The frontal part of $\mathrm{C} 1$ is composed of hemipelagites and turbidites that are deformed and compressed forming a system of thrusts, folds and pressure ridges, with individual pop-up blocks apparent in the frontal part of the MTD (Fig. 2). The greatest thickness of $\mathrm{C} 1$ deposits (up to $100 \mathrm{~m}$ ) is found in the central zone of $\mathrm{C} 1$ where the pressure ridges are higher (up to $10 \mathrm{~m} \mathrm{high}$ ) and larger (up to $2 \mathrm{~km}$ long) (Fig. 2a). The proximal part consists of tilted blocks (Fig. 2b) that become more deformed towards the south. Tilted blocks are identified in seismic profiles where reflectors dip in different directions. Moreover, tilted blocks form crests that are apparent in the seafloor. Groundtruthing evidence of the presence of tilted blocks comes from the bottom of Calypso piston core PSM3CS022 (Fig. 3). This core shows that a 4.7-m-thick debris flow deposit composed of mud with clay pebbles lies on top of the tilted blocks. These distinct seismic and lithological facies correspond to different degrees of deformation, which can be identified in the Calcium curve. When the degree of deformation is very high (debris flow deposit), the Calcium signal is very noisy (Fig. 3). Between the compressed frontal zone and the zone of tilted blocks, the sediment is strongly deformed, characterised by chaotic seismic facies and by a relatively smooth upper surface (Fig. 2). Since the pressure ridges and the crests are perpendicular to the mass movement, they provide information on the direction of the transport. The northern part of the Pianosa Slump comes from the area of the straight headwall parallel to the fault. The northernmost part moved slightly towards the northwest, while most of the sediment was transported in a southwest direction, towards the deepest part of the basin.

Multibeam bathymetry reveals the presence of many pockmarks located in the contourite drifts between areas B and C and close to MTDs in zone C (Fig. 1). The fluid escape paths over the Pianosa Slump are mainly found in the pressure ridges, in the crests and in the sidewall (Fig. 2b).

\section{Discussion and Conclusions}

Slope instability has been a recurrent process along the Pianosa Ridge, although the origin and the control factors could vary according to the location of the submarine landslides. The differences in size and volume between MTDs in area B and $\mathrm{C}$ are linked to an uneven sedimentation along the Pianosa Ridge related to the basement morphology and to bottom currents. Sediment accumulation on the slope in area $\mathrm{C}$ is much higher compared to area $\mathrm{B}$. Therefore, more sediment could be potentially mobilised by mass transport during a single event, generating larger submarine landslides. In area B bottom currents are accelerated due to the higher slope gradient, preventing sediment deposition.

Group B and C present some similarities in the time intervals of slope failure, since B1-C1 and B2-C2 are in similar ranges of age. In contrast, the other MTDs 


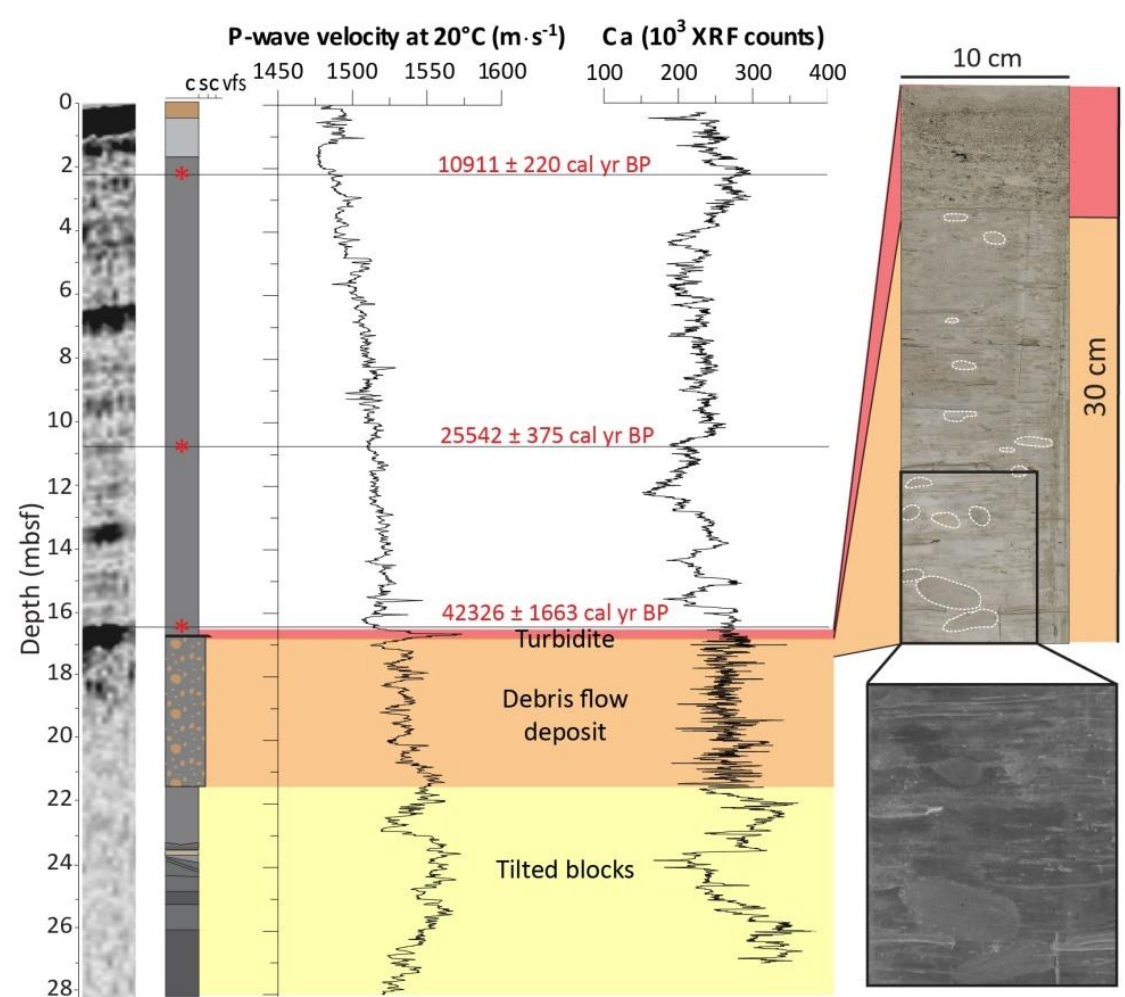

Fig. 3 From left to right: CHIRP seismic facies, core log, P-wave velocity and Calcium curves of Calypso piston core PSM3-CS022. Photo of the core and zoom with inverted colour. The red area shows a turbidite (peak in P-wave velocity), the orange area a debris flow deposit and the yellow area tilted blocks. Three calibrated radiocarbon ages are represented with red stars

are not synchronous. When $\mathrm{C} 3$ and $\mathrm{C} 4$ were formed, area B was in stable conditions (Table 1).

The main predisposing factor in areas A and B seems to be the steep slopes (8$20^{\circ}$ and $8-10^{\circ}$, respectively) (Fig. 1). Within the Elba Canyon, due to the Coriolis effect, bottom currents could produce a stronger erosion on the northern flank of the canyon, generating the observed canyon asymmetry with a steeper northern flank (Fig. 1). Incisions and oversteepening on the northern flank might have contributed to the formation of MTD A. In area B, six MTDs are stacked, and represent a relevant percentage (30\%) of the Pliocene-Quaternary deposit in the lower slope, suggesting that an important proportion of the sediment accumulated on the middle and upper slope was affected by mass transport. The formation of submarine landslides in area $\mathrm{C}$ (Fig. 1) seems to be much more complex. Multiple factors may predispose slope instability in this area. Bottom currents may have an important role since they provide sediment and generate incisions with higher slopes, corridors of non deposition or slight erosion (moat with slope of $15^{\circ}$; Fig. 1). In addition, layers of coarser sediment in contourite drifts seem to influence the 
location of failure planes (Miramontes et al. 2014) and could potentially stock more gas than the overlying mud. Numerous pockmarks affect the present day seafloor on top of the MTDs and contourite drifts (Figs. 1,2). Some of these pockmarks are clearly rooted on buried MTDs and turbidite lobes (Fig. 1). Such a configuration suggests that the emplacement of these sedimentary bodies might have influenced subsequent instability.

In the Pianosa Ridge the present-day seismicity is considered to be very low (Scisciani and Calamita 2009), while the area entered in a post-rift phase from the late Messinian (Pascucci et al. 1999). However, the location of the headwall of the Pianosa Slump next to a normal fault that affects the Pliocene-Quaternary record (Fig. 3) raises questions about the possible relationship between faulting and slope instability.

Acknowledgments We thank the Captain and the crew of the PRISME2 and PRISME3 cruises (2013) onboard R/V Atalante and R/V Pourquoi pas?, respectively. We are grateful to reviewers M. Rovere and C. Campbell for their valuable suggestions that improved the manuscript. The thesis of Elda Miramontes is co-funded by TOTAL and Ifremer as part of the scientific project TOTAL-Ifremer PAMELA. We thank projects LabexMER ANR-10-LABX-19-01 Axis 4 for lab support.

\section{References}

Angue Minto'o CM (2014) Enregistrements sédimentaires des changements climatiques et environnementaux pendant le quaternaire terminal sur la marge Est-Corse. PhD Thesis, Université de Perpignan, Perpignan, 309

Artale M, Gasparini GP (1990) Simultaneous temperature and velocity measurements of the internal wave field in the Corsican Channel (Eastern Ligurian Sea). Journal of Geophysical Research 95(C2):1635-1645

Cattaneo A, Jouet G, Charrier S, Thereau E, Riboulot V (2014) Submarine Landslides and Contourite Drifts Along the Pianosa Ridge (Corsica Trough, Mediterranean Sea). In: Submarine Mass Movements and Their Consequences: 6th International Symposium 37:435-445

Deptuck ME, Piper DJW, Savoye B, Gervais A (2008) Dimensions and architecture of late Pleistocene submarine lobes off the northern margin of East Corsica. Sedimentology 55:869-898

Miramontes E, Cattaneo A, Jouet G, Garziglia S, Thereau E, Gaillot A, Roubi A, Rovere M (2014) The Pianosa Contourite Depositional System (Corsica Trough, North Tyrrhenian Sea): stratigraphic evolution and possible role in slope instability. In: Van Rooij D, Rüggeberg A (eds). 2014. Book of Abstracts. 2nd Deep-Water Circulation Congress: The Contourite Log-book. Ghent, Belgium, 10-12 September 2014. VLIZ Special Publication 69:15-16

Pascucci V, Merlini S and Martini IP (1999) Seismic Stratigraphy of the Miocene-Pleistocene Sedimentary Basins of the Northern Tyrrhenian Sea and Western Tuscany (Italy). Basin Research 11:337-356

Reimer PJ and 29 others (2013). IntCal13 and Marine13 radiocarbon age calibration curves 050,000 years cal BP. Radiocarbon 55:1869-1887

Roveri M (2002) Sediment drift of the Corsica Channel, northern Tyrrhenian Sea. In: Stow DAV, Pudsey CJ, Howe JA, Faugères J-C, Viana A (eds) Deep-Water Contourite Systems: Modern Drifts and Ancient Series, Seismic and Sedimentary Characteristics. Geological Society of London Memoirs 22: 191-208

Scisciani V, Calamita F (2009) Active intraplate deformation within Adria: Examples from the Adriatic region. Tectonophysics 476: 57-72 